\title{
KAJIAN MUTU IKAN CAKALANG (Katsuwonus pelamis L) ASAP TERHADAP NILAI KADAR AIR DAN pH SELAMA PENYIMPANAN
}

\author{
Steven Tumonda', Hanny W. Mewengkang², Semuel M. Timbowo ${ }^{2}$ \\ ${ }^{1)}$ Mahasiswa pada Program Studi Teknologi Hasil Perikanan FPIK Unsrat Manado \\ ${ }^{2)}$ Staf pengajar pada Program Studi Teknologi Hasil Perikanan FPIK Unsrat Manado \\ Email: steventumonda@gmail.com
}

\begin{abstract}
Ikan cakalang (Katsuwonus pelamis L) mempunyai nilai ekonomis tinggi, baik sebagai komoditi ekspor maupun konsumsi lokal. Di Indonesia khususnya perairan Sulawesi utara produksi ikan cakalang termasuk tinggi. Tujuan dari penelitian ini adalah untuk mengetahui mutu dari ikan cakalang asap yang dijual di dua pasar tradisional, yaitu (A) Pasar Pinasungkulan Karombasan dan (B) Pasar Bersehati, Manado. Kadar air ikan cakalang asap yang dijual di pasar (B) tidak memenuhi syarat mutu SNI, yaitu $60 \%$ kadar air untuk ikan asap. Nilai pH ikan cakalang asap yang dijual di pasar A dan B selama penyimpanan suhu ruang masih memenuhi syarat mutu ikan ikan asap. Dari hasil penentuan kadar air dan nilai $\mathrm{pH}$ serta data yang diperoleh pada penelitian ini, dapat disimpulkan bahwa ikan cakalang asap yang dibeli dari Pasar A masih layak dikonsumsi sampai pada 2 hari penyimpanan dalam suhu ruang, dibandingkan dengan ikan yang dibeli dari pasar B.
\end{abstract}

Kata Kunci: Kajian Mutu, Ikan Cakalang (Katsuwonus pelamis L), Ikan Asap.

\section{PENDAHULUAN}

Indonesia merupakan negara maritim dengan laut yang cukup luas. Laut Indonesia memiliki potensi sumberdaya yang besar terutama potensi perikanan laut dari segi jumlah dan keragaman jenis. Luas laut Indonesia kurang lebih 5,8 juta $\mathrm{km}^{2}$ dengan garis pantai sepanjang $81.000 \mathrm{~km}$. Laut Indonesia yang luas menyediakan sumberdaya ikan laut dengan potensi lestari sebesar 6,4 juta ton per tahun yang tersebar diperairan wilayah Indonesia dan perairan Zona Ekonomi Ekslusif Indonesia (ZEEI). Jumlah tangkapan yang diperbolehkan di Indonesia sebesar $80 \%$ dari potensi lestari sumberdaya ikan laut yaitu sebesar 5,12 juta ton (Nurjanah et al. 2011 dalam Pumpente, 2014).

Pada dasarnya ikan merupakan bahan pangan yang mudah mengalami kerusakan biologis oleh enzim atau mikroorganisme pembusuk, oleh sebab itu ikan memerlukan penanganan khusus untuk mempertahankan mutunya. Proses kerusakan ikan yang paling umum terjadi adalah pembusukan yang disebabkan oleh bakteri (Supardi dan Sukamto, 1999 dalam Puspaningdyah, dkk. 2005).

Pengasapan merupakan cara pengolahan atau pengawetan dengan dengan memanfaatkan kombinasi perlakuan pengeringan dan pemberian senyawa kimia alami dari hasil pembakaran bahan bakar alami (Adawyah, 2007).

Di Sulawesi Utara khususnya kota Manado terkenal dengan produk ikan cakalang asap atau dengan nama lokal, yaitu cakalang fufu. Cakalang asap yang berkualitas dapat disimpan dalam waktu yang relatif lama, bisa bertahan sampai 1 minggu. Biasanya ikan Cakalang yang diasap memiliki ukuran sedang; memiliki panjang sekitar $30-50 \mathrm{~cm}$. Bahan bakar untuk pengasapan adalah sabut kelapa yang dipilih karena asapnya tebal, sehingga proses pengasapan relatif lebih cepat. Pengasapan dihentikan jika ikan berwarna kemerah-merahan, teksturnya empuk, kering, (Anonimous, 2013). Pada umumnya cakalang asap di Manado banyak terdapat di pasar tradisional dan ada juga sebagian sudah terjual di supermarket. Sebagai produk akhir, ikan asap diperoleh belahan memanjang berwarna coklat kemerahan, mengkilap, berbau khas ikan bakar, daging bagian luar agak keras, dan mempunyai daya awet 2-3 hari, hal ini dikarenakan suhu penyimpanan dilakukan pada suhu kamar yaitu $25-32^{\circ} \mathrm{C}$ dan daya tahannya tidak lama karena sudah mengalami pembusukan dan ditumbuhi kapang, (Dundu, 1986).

Kemunduran mutu ikan disebabkan oleh aksi enzimatis dan bakteri, kedua aksi ini mengurai komponen penyusun jaringan tubuh 
ikan sehingga menghasilkan perubahan fisik seperti daging ikan menjadi lunak dan perubahan kimia menghasilkan senyawa yang mudah menguap dan berbau busuk (Hadiwiyoto, 1993).

Pangan menjadi perhatian mendasar bagi kesehatan publik dan mendukung kepentingan perdagangan/ekspor.Oleh karena itu, produk perikanan perlu ditangani dengan benar dari hulu hingga hilir melalui penerapan good practice untuk menjamin mutu dan keamanannya. Pemerintah telah menetapkan persyaratan sanitasi yang wajib dipenuhi dalam kegiatan atau proses produksi dalam UU No. 27 Tahun 1996 tentang pangan, contoh Keputusan Dirjen POM No. KH.00.04.3-3.011 Tahun 1996 tentang pedoman penerapan cara produksi makanan yang baik (Sulistijowati. R, $d k k$. 2011).

Penelitian ini bertujuan untuk mengetahui mutu dari ikan cakalang asap yang dijual di dua pasar tradisional, yaitu A. Pinasungkulan Karombasan dan B. Pasar Bersehati, Manado. Manfaat dari penelitan ini diharapkan dapat memberikan informasi tentang karakteristik mutu pada ikan cakalang asap khususnya yang dijual di dua pasar yaitu, pasar Pinasungkulan Karombasan dan pasar Bersehati, Manado

\section{METODOLOGI PENELITIAN}

\section{Tempat dan Waktu Penelitian}

Pelaksanaan penelitian ini dilakukan di Laboratorium Teknologi Penanganan dan Pengolahan Hasil Perikanan dan Laboratorium Pengendalian Mutu Hasil Perikanan, Fakultas Perikanan dan Ilmu Kelautan Universitas Sam Ratulangi Manado. Sedangkan, waktu penelitian dilakukan pada bulan April sampai Mei 2016.

\section{Alat dan Bahan}

Alat yang digunakan dalam penelitian ini untuk analisa kadar air: oven, desikator, cawan porselin, mortal dan pestle, spatula, penjepit dan timbangan analitik dan untuk analisa kadar $\mathrm{pH}$ ialah $\mathrm{pH}$ meter, beker glass, spatula dan timbangan analitik. Sedangkan bahan yang digunakan dalam penelitian ini yaitu: ikan cakalang asap, akuades, buffer $\mathrm{pH} 4$ dan buffer $\mathrm{pH} 7$.

Metode yang akan digunakan yaitu metode penelitian yang bersifat deskriptif yaitu menganalisa dan memberikan gambaran secermat mungkin mengenai suatu individu, keadaan, gejala atau kelompok tertentu (Koentjorongingrat, 1989).

\section{Perlakuan}

Jenis produk ikan asap yang dilakukan dalam penelitian ini adalah ikan cakalang asap. Perlakuan yang diberikan yaitu:

1. Lokasi pengambilan sampel

A: Pasar Pinasungkulan Karombasan

B: Pasar Bersehati

2. Lama penyimpanan pada suhu ruang, $30 \mathrm{oC}$

$\mathrm{H}_{0}$ : 0 hari (tanpa penyimpanan)

$\mathrm{H}_{1}$ : 1 hari penyimpanan

$\mathrm{H}_{2}: 2$ hari penyimpanan

Tiap 1x24 jam diamati mutu dari ikan cakalang asap dengan 3 kali ulangan setiap perlakuan.

\section{Prosedur Penelitian}

Penelitian ini dilaksanakan dengan prosedur sebagai berikut:

Produk ikan asap yang digunakan sebagai sampel dalam penelitian ini adalah ikan cakalang asap yang dibeli dari pedagang ikan yang tersebar di dua Pasar tradisional terbesar di kota Manado yaitu Pasar Pinasungkulan Karombasan dan Pasar Bersehati Manado. Sampel setelah dibeli dikemas dalam kantong plastik yang bersih, kemudian dibawah ke laboratorium untuk dianalisa mutunya.

Peralatan yang digunakan dalam penelitian ini telah dipersiapkan terlebih dahulu untuk memudahkan dalam hal pengujian sampel uji. Untuk langkah selanjutnya sampel ikan asap dianalisa mutu (Kadar air dan $\mathrm{pH}$ ) hari ke0 , selanjutnya sampel disimpan di suhu ruang. Pada penelitian selanjutnya yakni analisa mutu ikan asap dilakukan untuk analisa pada penyimpanan hari ke-1 dan penyimpanan hari ke-2 pada suhu ruang.

\section{Pengamatan dan Pengukuran}

Untuk melihat pengaruh perlakuan dilakukan pengamatan dan pengukuran terhadap:

1. Kadar air (AOAC, 1995)

2. Nilai $\mathrm{pH}$ dengan menggunakan $\mathrm{pH}$ meter digital ADWA AD1000 (AOAC, 1995)

Prosedur Analisa Kadar Air (AOAC, 1995)

1. Cawan porselen beserta tutupnya yang telah dicuci bersih, dalam keadaan kosong 
dimasukkan ke dalam oven yang temperaturnya $100-105^{\circ} \mathrm{C}$ kurang lebih selama 1 jam.

2. Cawan dipindahkan ke dalam desikator dan didinginkan selama 30 menit, kemudian ditimbang beratnya.

3. Ke dalam cawan porselen dimasukkan sampel sebanyak 2-3 gram, lalu ditimbang.

4. Cawan porselen yang telah berisi sampel dimasukkan ke dalam oven yang temperaturnya $100-105^{\circ} \mathrm{C}$ selama 3 jam.

5. Pengeringan dan penimbangan dilakukan terus sampai diperoleh berat yang konstan.

6. Setelah diperoleh berat yang konstan, sampel dipindahkan ke dalam desikator dan didinginkan selama 30 menit, kemudian ditimbang.

Perhitungan:

Kadar Air \%= $\frac{\text { (berat cawang+sampel awal-berat cawang }+ \text { sampel akhir) }}{\text { berat sampel }} \times 100 \%$

\section{Prosedur Analisa Kadar pH (AOAC 1990)}

1. Sampel ditimbang sebanyak 5 gram kemudian ditambahkan akuades $10 \mathrm{ml}$ dan dihomogenkan selama satu menit.

2. Sampel yang sudah homogen dipindahkan ke dalam beker glass $100 \mathrm{ml}$, lalu diukur pHnya menggunakan alat $\mathrm{pH}$ meter digital ADWA AD1000.

3. Sebelum $\mathrm{pH}$ meter digunakan, terlebih dahulu dilakukan peneraan dengan menggunakan larutan buffer $\mathrm{pH} 4$ dan $\mathrm{pH} 7$.

4. Nilai $\mathrm{pH}$ sampel adalah nilai yang ditunjukkan oleh monitor digital pada posisi konstan.

\section{HASIL DAN PEMBAHASAN}

\section{Asal Bahan Baku}

Bahan baku ikan cakalang asap yang dijadikan sampel pada penelitian ini dibeli dari 2 (dua) pedagang yang tersebar di dua pasar tradisional Manado, yaitu pasar Pinasungkulan Karombasan dan pasar Bersehati.

Bahan baku ikan cakalang asap yang digunakan sebagai sampel merupakan produk ikan asap dari dua pedagang dan dua pasar pasar yang berbeda, untuk pedagang (A) Pasar Pinasungkulan Karombasan ikan asap yang dijual adalah ikan asap yang dipesan dan dikirim langsung dari kota Bitung, sedangkan pedagang (B) pasar Bersehati ikan asap yang dijual adalah ikan asap hasil olahan sendiri. Ikan cakalang dari kedua pedagang ini kemudian diuji di Laboratorium. Uji mutu yang dilakukan adalah analisa Kadar air dan uji pH. Pengujian dilakukan sebanyak dua kali ulangan.

\section{Penentuan Kadar Air}

Air merupakan kandungan yang terbesar dalam ikan. Air merupakan sarana mikroorganisme untuk berkembang, sehingga proses pengasapan memiliki tujuan untuk mengurangi kadar air dalam ikan dan diharapkan dapat memperpanjang umur simpan ikan asap. Berdasarkan data di tabel tersebut dapat dilihat bahwa nilai rata-rata kadar air tertinggi pada daging ikan sampel A adalah $56,5 \%$ dan daging ikan sampel B adalah $63,16 \%$ untuk ikan cakalang asap yang disimpan selama 2 hari, sedangkan nilai kadar air terendah untuk daging ikan sampel $\mathrm{A}$ adalah $51,67 \%$ dan daging ikan sampel B adalah 53,67\% pada ikan cakalang asap yang belum diberi perlakuan penyimpanan (0 hari). Hal ini menunjukkan bahwa proses pengasapan dapat menghasilkan produk dengan kadar air yang lebih rendah.

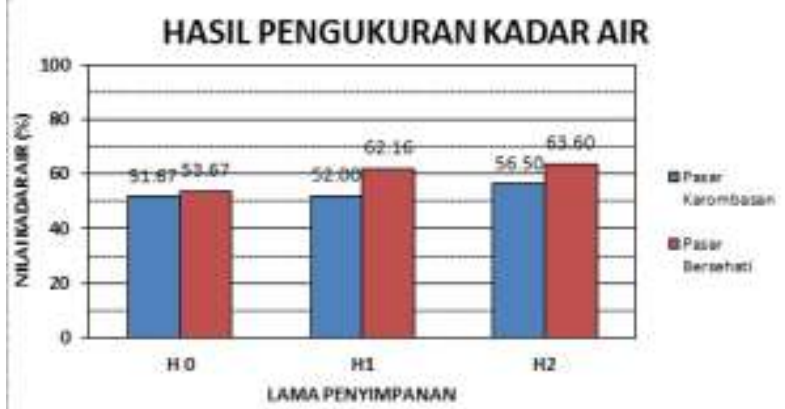

Gambar 1. Nilai rata-rata kadar air sejak 0-2 hari penyimpanan.

Keterangan:

HO : Hari ke nol (tanpa penyimpanan)

H1 : Hari ke 1 (hari pertama penyimpanan pada suhu ruang)

H2 : Hari ke 2 (hari kedua penyimpanan pada suhu ruang)

Menurut Wibowo (2000) perubahan kadar air pada proses pengasapan diakibatkan karena panas dan penarikan air dari jaringan tubuh ikan oleh penyerapan berbagai senyawa kimia dari asap. Hal ini diduga karena produk yang dihasilkan dari proses pengasapan dan pengeringan dapat menghilangkan kandungan air sampai batas tertentu dalam daging ikan sehingga menghambat aktivitas mikroba karena air merupakan media yang dapat menurunkan daya awet produk. Afrianto dan Liviawaty (1989) menyatakan bahwa pengawetan ikan dengan pengasapan merupakan salah satu upaya yang dilakukan manusia dalam memperpanjang daya simpan ikan. Di sisi lain menurut 
Moeljanto (1992) pada proses pengeringan kandungan air dapat diturunkan sampai 30\% sehingga aktivitas bakteri akan terhambat.

Gambar 1 di atas menunjukkan bahwa kadar air produk cenderung meningkat selama proses penyimpanan, tetapi masih pada kisaran $15 \%$.

Kadar air ikan cakalang asap selama penyimpanan dari 0 hari ke 2 hari cenderung meningkat. Hal ini diduga disebabkan oleh karena kelembaban ruangan yang tinggi, dan mengakibatkan produk menyerap air dari lingkungan. Menurut Purnomo (1995) dalam Kaparang, $d k k$. (2013) naiknya kadar air disebabkan karena kelembaban ruangan penyimpanan lebih tinggi dari produk sehingga produk akan menyerap air yang mengakibatkan kadar air produk tinggi. Standar kadar air SNI untuk ikan asap adalah 60\% (SNI 2725.1-2009). Mengacu pada data di atas maka ikan asap yang diambil dari pasar Pinasungkulan Karombasan selama penyimpanan 2 hari masih memenuhi standar SNI untuk ikan asap karena berada di bawah $60 \%$,sedangkanikan cakalang asap yang diambil dari pasar bersehati melebihi batas maksimal standar yang diisyaratkan oleh SNI.

Tingginya kadar air ini disebabkan oleh lama waktu pengasapan yang relatif pendek dan suhu yang fluktuatif menyebabkan proses penguapan air menjadi tidak stabil dan menyebabkan nilai kadar air masih tinggi. Menurut Saleh, $d k k$. 1995, terjadinya penurunan kadar air akibat penguapan dari produk karena pengaruh suhu udara dan kelembaban lingkungan sekitar. Tingginya kadar air pada ikan asap yang disimpan tanpa dikemas dalam suhu kamar dapat mempengaruhi kualitas ikan asap yang dihasilkan.

\section{Nilai pH (Tingkat Keasaman)}

Nilai $\mathrm{pH}$ merupakan salah satu indikator dari kualitas ikan asap, yang dapat mempengaruhi kadar protein, fenol, formaldehid, dan asam organik. Adapun nilai pH tertinggi untuk sampel A adalah 6,02 dan untuk sampel B adalah 5,89 pada ikan cakalang asap yang disimpan selama 2 hari dan nilai $\mathrm{pH}$ terendah untuk sampel $\mathrm{A}$ adalah 5,77 dan untuk sampel B adalah 5,71 pada ikan cakalang asap dengan penyimpanan pada suhu ruang. Perbedaan $\mathrm{pH}$ terjadi akibat tingkat atau aktifitas dari bakteri asam laktat dan jumlah dari asam-asam organik dalam ikan asap tersebut (Swastawati, $d k k$. 2013).
Menurut Winarno, dkk. (1988) dalam Kaparang, dkk. (2013) bahan-bahan asap seperti formaldehida, aseton dan fenol mempunyai sifat membunuh bakteri, sementara asam yang mudah menguap dalam asap akan menurunkan $\mathrm{pH}$ pada permukaan daging ikan dan memperlambat pertumbuhan mikroorganisme. Selanjutnya menurut Ilyas (1972), menyatakan bahwa akibat dari proses pengasapan dapat menyebabkan turunnya kadar air, tetapi naiknya kadar asam dan adanya pengendapan berbagai senyawa kimia asap.

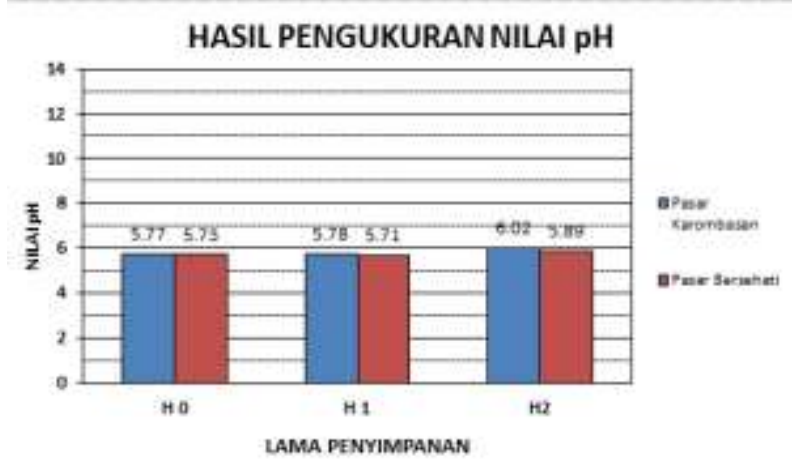

Gambar 2. Pengukuran pH ikan cakalang asap selama penyimpanan pada suhu ruang.

Keterangan:

HO : Hari ke nol (tanpa penyimpanan)

H1 : Hari ke 1 (hari pertama penyimpanan pada suhu ruang)

H2 : Hari ke 2 (hari kedua penyimpanan pada suhu ruang)

Berdasarkan Gambar 2, dapat diketahui bahwa peningkatan nilai $\mathrm{pH}$ selama penyimpanan 0 hari sampai 2 hari pada suhu ruang masih bisa dikatakan stabil. Peningkatan nilai $\mathrm{pH}$ selama penyimpanan suhu ruang disebabkan karena aktfitas enzim dan bakteri mulai berlangsung, Wally, $d k k$. (2015). Chamidah, dkk. (2000) menyatakan bahwa selama penyimpanan terjadi penguraian protein menjadi senyawa basa antara lain amoniak. Nilai $\mathrm{pH}$ bahan pangan selama penyimpanan dapat berubah karena adanya protein yang terurai oleh enzim proteolitik dan bantuan bakteri menjadi asam karboksilat, asam sulfide, amoniak dan jenis asam lainnya. Menurut Riyanto, dkk. (2006) nilai $\mathrm{pH}$ berhubungan dengan aktivitas bakteri dan enzim yang secara alami sudah ada. Kondisi ini menyebabkan peningkatan $\mathrm{pH}$ yang mengakibatkan pembentukan ammonia TMA dan turunannya. Nilai $\mathrm{pH}$ merupakan salah satu indikator yang digunakan untuk menentukan tingkat kesegaran ikan. Pada proses pembusukan ikan, perubahan $\mathrm{pH}$ daging sangat besar peranannya karena 
berpengaruh terhadap proses autolysis dan penyerangan bakteri. Batas $\mathrm{pH}$ maksimum ikan yang masih disebut segar yaitu 6,8. nilai $\mathrm{pH}$ yang didapat pada penelitian ini masih termasuk dalam kriteria mutu yang baik.

\section{KESIMPULAN DAN SARAN}

\section{Kesimpulan}

1. Kadar Air ikan Cakalang (Katsuwonus pelamis L) Asap yang dijual di pasar B selama penyimpanan 2 hari pada suhu ruang tidak memenuhi syarat mutu SNI dibandingkan dengan ikan yang dijual di pasar A yang memenuhi syarat mutu SNI, yaitu $60 \%$ kadar air untuk ikan asap.

2. Nilai pH ikan Cakalang (Katsuwonus pelamis L) Asap yang dijual di pasar A dan B selama penyimpanan 2 hari pada suhu ruang masih memenuhi syarat mutu ikan asap.

3. Dari hasil penentuan kadar air dan nilai $\mathrm{pH}$ serta data yang diperoleh pada penelitian ini, dapat disimpulkan bahwa ikan cakalang (Katsuwonus pelamis L) asap yang dibeli dari Pasar A masih layak dikonsumsi sampai pada 2 hari penyimpanan dalam suhu ruang, dibandingkan dengan ikan yang dibeli dari pasar B.

\section{Saran}

Perlu dilakukan penelitian lanjutan untuk analisis mutu pada ikan cakalang (Katsuwonus pelamis L) asap yang dijual di semua pasar tradisional Manado, Sulawesi Utara agar mutunya lebih terjamin.

\section{DAFTAR PUSTAKA}

Adawyah., 2007. Pengolahan dan Pengawetan Ikan., Prinsip Pengasapan., Bumi Aksara, Jakarta.

Afrianto, E., dan E. Liviawaty. 1989. Pengawetan dan Pengolahan Ikan. Kanisius. Yogyakarta.

Anonimous.,2013., http://sulutonline.com/berita/2559cakalang-fufu-khas-manado.html. 25 Februari 2015, Pukul 13 : 31 Wita.

[AOAC] Assocation of Official Analytical Chemistry., 1995., Official Methods of Analysis. Penentuan Kadar Air Bahan Pangan.,

[AOAC] Assocation of Official Analytical Chemistry. 1990.,Official Methods of Analysis., Penentuan Kadar Derajat Keasaman $(\mathrm{pH})$.,

Badan Standarisasi Nasional. 2009. SNI 2725.1.2009. Ikan Asap-Bagian 1: Spesifikasi. Jakarta.
Badan Standarisasi Nasional. 2009. SNI 2725.2.2009. Ikan Asap-Bagian 2: Persyaratan bahan baku. Jakarta.

Badan Standarisasi Nasional. 2009. SNI 2725.3.2009. Ikan Asap-Bagian 3: Penanganan dan Pengolahan. Jakarta.

Chamidah, A., Tjahyono, A dan Rosidi, D. 2000. Penggunaan Metode Pengasapan Cair dalam pengembangan Ikan bandeng Asap Tradisional. Jurnal Ilmu-ilmu Teknik.Volume 12. No. 1

Dundu.B, 1986.Penelitian Flora Bakteri Pada Ikan Cakalang (Katsuwonus pelamis) dan Produk-produk di Sulawesi Utara.Tesis. Universitas Sam Ratulangi. Manado.

Hadiwiyoto, S., 1993. Teknologi Pengolahan Dan Pengawetan Hasil Perikanan Jilid 1. Liberty. Yogyakarta.

Kaparang, R., Harikedua, S., Suwetja, I. 2013.Penentuan Mutu Ikan Tandipang (Dussumieria acuta C.V) Asap Kering selama Penyimpanan suhu Kamar.Jurnal Media Teknologii Hasil Perikanan.UNSRAT. Manado.Vol.1,No.1,Februari 2013

Koentjorongingrat, 1989.Metode-metode Penelitian Masyarakat. PT. Gramedia. Jakarta.

Moeljanto, R., 1992. Pengolahan Dan Pengawetan Hasil Perikanan. PT. Penebar Swadaya. Jakarta

Pupente O. 2014. Kandungan Basah Purin Pada Ikan Teri (Stolephorus sp) dan Ikan Sarden (Sardinella gibbosa).Skripsi Fakultas Perikanan dan Ilmu Kelautan.UNSRAT Manado.

Puspaningdyah E, Martini, Sri Yuliawati. 2005. Kontaminasi Staphylococcus aureus Pada Ikan Asap Di Tingkat Produsen Dan Penjual Di Semarang.Jurnal Universitas Muhammadiyah Semarang.

Riyanto R., A. Kusmarwati, Dwiyitno 2006. Pengaruh Penyimpanan Ikan Pada Suhu Kamar Terhadap Mutu Kimiawi, Mikrobiologi, dan Organoleptik. Jurnal Pasca panen dan Bioteknologi Kelautan dan Perikanan Vol 1, No 2, Hal 111-116.

Rieny Sulistijowati S., Otong Suhara Djunaedi, Jety Nurhajati, Eddy Afrianto, Zalinar Udin. 2011. Mekanisme Pengasapan Ikan. UNPAD PRESS. Trisatya.

Saleh M., Irwandi.,F.G. Winarno., dan Y. Haryadi. 1995. Pengaruh Perlakuan Larutan Perendaman Terhadap Kadar Urea daging Cucut Segar dan Mutu Daging Asapnya. Jurnal Penilitian Perikanan Indonesia 1..

Swatawati F. Surti T, Agustini T W, dan Riyadi P H. 2013. Karakteristik Kualitas Ikan Asap Yang Diproses Menggunakan Metode Dan Jenis Ikan Berbeda. Jurnal Aplikasi Teknologi Pangan Vol. 2 No. 3.

Wibowo., S. 2000. Industri Pengasapan Ikan. Penebar Swadaya. Jakarta

Wally. E., Mentang. F., Montolalu. R. 2015 .Kajian Mutu Kimiawi Ikan Cakalang (Katsuwonus pelamis L) Asap (fufu) Selama Penyimpanan Suhu Ruang dan Suhu Dingin. Jurnal Media Teknologi Hasil Perikanan.Vol 3. NO 1. 